\title{
(Re)producing habits in international negotiations: a study on the translation of collocations
}

\author{
Esther Monzó Nebot
}

\begin{abstract}
The paper aims to contribute data to the subservient habitus hypothesis explored in Interpreting and Translation Studies, where interpreters and translators are said to be especially sensitive and keen to reproduce social and textual norms, usually dictated by other agents in the field. After exploring the use of this hypothesis in the field, the case study is preceded by a brief account of special features of translation in international organizations and the key elements of the use of legal translation at the World Trade Organization (WTO). The selection of the corpus of study and the target-oriented approach are justified before briefly comparing the traditions in the study of phraseology in English and Spanish. A method drawing from both traditions is explained and then applied to two subcorpora of legal texts in order to establish patterns that can help us see how subservient or subversive translators' behavior can be.
\end{abstract}

Keywords subservient habitus hypothesis, translational norms, legal translation, international organizations, collocations

\section{Introduction}

One of the most widely tested hypotheses in Interpreting and Translation Studies (TS) is that translators are "creatures of habit" (Kenny 1998). They have a special relationship to norms and conventions, as they are usually (albeit unknowingly) committed supporters of standards and patterns, sometimes seen as overtly conformist and submissive (Wolf 2007) and reluctant to take risks (Pym 2008). Studies on translators' habiti have focused on developing the concept and testing its applicability to translators in different systems (Simeoni 1995, Wolf 1999, Gouanvic 2002, Inghilleri 2003, Sela-Sheffy 2005, Meylaerts 2010). Definitions have closely followed Bourdieu's theory of social practice, which is especially significant in TS for both the sociologist's own interest in translation (Bourdieu 2002) and his reception in the field. Part of his ontological system has been pervasive in the discipline for the last decades. The explanatory powers of the notions, even outside of Bourdieu's conceptual complex, seem to withstand the test of time.

Within the field of TS, however, not all areas have shared the same keen interest to test the subservient habitus hypothesis bequeathed to the discipline (Simeoni 1998), or even Bourdieu's theoretical framework. Legal interpreting and translation (LIT), for instance, has been relatively impervious to Bourdieu's work (exceptions including Vidal Claramonte 2005), Monzó Nebot 2005, Valero Garcés/Gauthier 2010). The protracted debate on core notions such as loyalty or neutrality supports a tacit or explicit agreement on not only LIT but also LIT studies being aligned with a functionalist theory of translation (Garzone 2000, Prieto Ramos 2014). This approach endorses the introjection (cf. Bourdieu 1977: 26) of the norms found in the target group and a resulting subservience to the client and their needs, as perceived by or instructed to translators. At the edge of translation, the power to define LIT is claimed de facto by Law Studies, whose quest for the knowledge of the source legal system and language stresses both source-orientedness and an equivalence paradigm (cf. Condon 2010), where es- 
sentialist views are impinged upon practitioners. Also in TS, the equivalence paradigm calls for the study of the legal systems and individualized discussions of equivalences (cf. Šarčevič 2000). Both positions represent and reproduce a prescriptive approach to LIT.

Changes in society and LIT scope cast doubts on the dominant views and solutions as heterodox practices call for our attention (cf. Villeneuve 2001, Fiola 2004, Inghilleri 2010, Mingxing 2012, Guo 2014). A new wave of critical studies (cf. Vidal Claramonte/Martín Ruano 2003) have been focusing on the insights from real practice that shake up the status-quo bias in scholarly work. The more we know from different traditions across languages, cultures, and time, the more undeniable the diversity of coexisting definitions of LIT and its core notions becomes. A new zeitgeist is advancing ethnographic studies (Valdés et al. 2000, Inghilleri 2003, Koskinen 2008, Gallez/Maryns 2014), which present human experience as fragmented and provide specific cases and systematically taken data for a context-dependent discussion. "The turn to ethnography promises greater attention to agency and a focus on non-discursive practices and the potential of resistance to discourses otherwise seen as totalizing and reductionist to individual freedom." (Lie 2013: 202)

Studies focus on human groups, whose norms (cf. Toury 1978) are then related and compared to other results, aiming at constructing a LIT theory that can fit an ever-changing reality. LIT is thus viewed as "the other types of translational activities", that is, "a norm-governed human and social behavior" (Cao 2013: 422). Norms replaced the notion of equivalence in Descriptive Translation Studies (DTS) to refer to regularities in translational behavior. They determine the position of a translation or system of translations between adequacy (that is source-orientedness) and acceptability (target-orientedness) and they act as "the intermediating factor between the system of potential equivalence relationships and the actual performance" (Toury 1981: 24). "Norms imply that there is a course of action which is more or less strongly preferred because it is accepted as proper or correct or appropriate." (Hermans 2012: 4263)

Šarčevič (1997) reviewed what norms have been dictated to and reproduced by legal translators through history, arguing that "legal translation remained under the grip of tradition much longer than other areas of translation" (Šarčevič 1997: 23). Equal language rights movements in multilingual and multiethnic societies changed the norms by stressing the citizens' rights to access legal texts which are not distorted by linguistic or stylistic obligingness to dominant law-making languages (cf. Šarčevič 1997 on the Rossel-Cesana controversy). The extent to which adequacy or acceptability is incorporated in translators' habiti and reproduced through their social and textual behavior remains an open question for descriptive studies in LIT.

By taking a descriptive microperspective, this study will approach the habitus of translators working in international organizations to contribute some data to the debate on how neutral, subservient, participatory, and subversive translators' habitus is. Of course, habitus is not to be understood in exclusively textual terms, and therefore this can only be added to other contributions in the field as a step towards deciphering the complexities and dynamics of LIT.

\section{What is so special about international organizations?}

The Paris Peace Conference (1919) marked a major milestone in the international political arena. Interstate negotiations changed scenario and moved from diplomats' bureaus to a public agora where discussions were relatively open. The resulting League of Nations (1920) set 
the tone of an unprecedented institutional development. Liaison interpreting had been the mode par excellence in overcoming interlingual and intercultural differences between diplomats. Thereafter, translation would assume a crucial everyday role to make intense worldwide political cooperation possible. Translation policies and norms have been established through an intensive translation activity and thanks to technological developments and international resources, they have reached beyond institutional limits. Translators all over the world look for help in institutional multilingual glossaries and databases. Despite their easy access, these solutions are tailored to the specific needs and working procedures of the organizations that created them in the first place and they are heavily influenced by two special features that are particularly relevant for TS: "foundational multilingualism" and "multilingual drafting".

\subsection{Foundational multilingualism and multilingual drafting in international organizations}

Foundational multilingualism, as the linguistic policy agreed on at the inception of an international organization, acts as recognition of the political value of the parties to the institution or the original founding parties. The first session of the UN General Assembly established Chinese, English, French, Russian, and Spanish as the official languages of the UN (UN General Assembly 1946), to which Arabic was added in 1973 (UN General Assembly 1980). The European Union is an extraordinary case, as each and every one of the members choose one language upon accession that will be from then on considered "official", now amounting to 24. That does not mean, however, that the daily work at the secretariats or even discussions are conducted in all languages, as English is nowadays as dominant as French used to be at the time of the Paris Conference (cf. Baigorri Jalón 1999). The UN system relies mostly on English, French, and Spanish as working languages, and English is sometimes referred to as the only working language in the EU (Ammon 2006). Special attention must be paid to the Organisation of African Unity, whose Charter is worded in very ambiguous terms, whereby English and French texts have to be made available, whereas African languages are official and yet should be used only "if possible" (OAU 1963: art. 24 and 9). The subsequent incorporation of Arabic, together with Portuguese, gave some meaning to the provision, although no other African language has been used as an official or working language (Ajulo 1985).

The practical result of foundational multilingualism is that documents are produced in the (non-ambiguous) official languages at (more or less) the same time. Following the Vienna Convention on the Law of Treaties (UN 1969), translations in the official languages are called "texts" and any other translation is called a "version" (ILC 1966: 874 $4^{\text {th }}$ meeting, $\$ 7$, and $93^{\text {rd }}$ meeting, $\mathbb{\$} 41$ ). All texts embody one single treaty (ILC 1966: $874^{\text {th }}$ meeting, $\mathbb{\$} 10$ ) and the responsibility to reconcile eventual differences between texts lies on the interpreter of the treaty (UN 1969: art. 33.4) as their meaning is presumed to be the same (UN 1969: art. 33.3).

That rule has resulted in two disciplinary views clashing and jostling in the LIT field claiming the right to define what a legal translation is. From a legal perspective we must suspend our disbelief and accept that all texts are the result of the discussions and drafting efforts of State representatives, even though the travaux préparatoires are public and do acknowledge the existence of translations. Lawyers can therefore claim exclusive jurisdiction over any interpretation of those texts, linguistic, textual, and otherwise. Applying a translational doxa, however, we can use session proceedings and other available sources to determine which texts were authored by State representatives and which texts were entrusted to translators, albeit later discussed and possibly amended in the room. TS can thus claim its jurisdiction over the 
study of norms, either linguistic or otherwise, and of translation as a means to canonize a text within the international legal system (cf. Berman 1988, Venuti 1992: 7).

Multilingual drafting, on the other hand, stresses the fact that documents in international organizations are collective endeavors. Drafters rarely share one language and, with or without interpreters and translators, discussions and related work are held and conducted in different languages using terms from different legal traditions. Both "multilingual drafting" and "co-drafting" are used although not always interchangeably. Jurilinguists suggested co-drafting as the ideal formula to coordinate two different legal traditions in bilingual legislation (cf. Covacs 1979, Fernbach 1995). The solution was to have a team of lawyers and jurilinguists work together and, when possible legal mismatches were identified, to gloss all versions (texts) so that correspondence was ensured and cultural differences were bridged. Co-drafting was implemented at the national level (Levert 1999, Gémar distinguishes co-drafting from any translational practice, e.g. 2013) but was rare in international negotiations (Shelton 1997 reports one such case). The most widespread use, however, refers to texts being drafted in one language, then translated, and then submitted for discussion or approval in the different languages simultaneously (cf. Koskinen 2000, Cao 2007, Biel 2014).

\subsection{The making of norms}

In this most common formula lawyers and translators work at different desks. Documents are sometimes discussed using different languages (proceedings of the International Law Commission attest to this practice), drafted in one (generally English, or Englishes), and transferred to translation sections whilst still being negotiated. Translators discuss solutions in (multidisciplinary) teams, establish prescriptive equivalences (circulated through memos and glossaries), and point out incongruences or comprehension problems in original versions when working on or upon submitting translations. Amendments are suggested for, and introduced in, any and all linguistic versions at the same time. In this process formulations are negotiated across languages and dialects, among translators but also delegates, counselors, and technical staff. The resulting texts are the product of complex, long, and detailed negotiations, and have an impact on the institutional future, and language. As representatives of different (legal) languages, cultures, and dialects, each negotiating party has contributed its share to a specific jargon which builds a common ground for translators from different Member States.

Approved documents are then processed and used as reference for future texts. International organizations provide computerized systems so that both drafters and translators have easy access to their documents in all official languages, thereby ensuring consistency across languages when quoting foundational agreements, referring to previous documentation, or contesting specific clauses. Organizations also have (official and informal) terminological databases that provide term equivalences in the official languages. These tools are especially convenient for the work of translators (and revisers) but they underscore the importance of negotiation and agreement: once a linguistic version has been agreed upon, changes would violate the expressed will of members.

\subsection{Tools for consistency}

Consistency across linguistic versions of institutional documents is crucial (cf. Condon 2012). Citizens may call upon any linguistic version of a given document, which of course should 
provide the same rights and obligations whichever the language (cf. Aceves 1996), and delegates may be able to renegotiate covenants if inconsistencies or "mistranslations" are alleged. Consistency is not only applied across languages but also across texts within one same language. Reusing previous translations and formulae is not only a question of economy but also a requisite to respect the highly negotiated nature of organizational language. To ensure both drafters and translators/revisers have access to previously negotiated and approved versions, human and technological resources are established.

Before delivering a document to the translation service, most organizations provide a reference service where the secretariat's staff mark the parts of the document that have been taken up from existing official documentation. Translators are then given the texts and the translation support service (be it a department under this or any other name, or assigned personnel from other sections) offers and maintains a documentation system consisting of translation memories, terminological databases, and parallel corpora. Some organizations also provide basic style guidelines and specific instructions for particular genres or for documents sent by specific committees. Translators may or may not use these tools, but beyond ensuring consistency they will no doubt help them reach the minimum productivity rate for their job assessments. Revisers will then be assigned the translated document. These are professionals who have typically been working for the institution for a considerable time and their mission is to ensure consistency with the institutional norms in which they have been socialized. They are also available for questions and discussions with novice translators and sometimes they hold law-related seminars and practice-based workshops where different solutions for specific problems are discussed in detail.

Several of these tools and resources have been described and explored elsewhere. ${ }^{1}$ The intention here is to establish the simultaneity and comprehensiveness of both human and technological measures aimed at preserving the institutional norms. Under these circumstances, can some self-determination escape control? Does innovation have a place in the institutional machine? Beyond explicit rules and equivalences enshrined in databases, do translators abide by common patterns? Parallel corpora allow both for translators and researchers to access previous decisions of any linguistic realizations. Will translators albeit implicitly recognize phraseological units and formulaic language as part of the textual and organizational consistency when drafting new texts? Do they take risks and introduce changes in the organizational culture or do they take a subservient role to norms seeking the revisers' and the institutions' approval?

To attempt to answer these questions, the collocations used in one of these organizations, the World Trade Organization (WTO), will be analyzed. The research will focus on the Spanish versions of texts as these are usually authored by translators and not by delegates or other professional and technical staff (cf. Condon 2010).

\section{Brief notes on the World Trade Organization}

This section will summarize the key data on the World Trade Organization (WTO) that will be used for corpus selection. ${ }^{2}$ The WTO was founded in 1995 after the successful Uruguay round

For an overview of the use of corpora in international organizations cf. Monzó Nebot 2011. The tools used at the WTO have been described in Pasteur 2013.

2 Cf. Narlikar (2005) for an overview and Prieto Ramos (2013) for an account of the translation work conducted at the WTO. 
of negotiations that became an international agreement to establish rules and policies for international trade and an international organization to pursue and continue cooperation. The WTO provides a forum for trade negotiations and ensures agreements are honored through training, policy reviews, and dispute settlement. Multilateral agreements reached on its three major areas of interest (trade in goods, trade in services, and intellectual property) are administered and supervised through councils, specialized committees, working groups, and working parties. The fundamental agreements are together referred to as the Final Act of the 1986-1994 Uruguay Round, although they have been entered into at different times. The daily work at the Secretariat (Geneva, Switzerland) is conducted in English, French, and Spanish. Topics cover a wide range of specialisms, but given the organization's legislative and adjudication functions, law-related work and LIT hold a prominent position, especially considering the "ever-expanding body of dispute settlement reports" (Cook 2012: 49). This poses structural and procedural demands.

The Dispute Settlement Body (DSB) operates under the Dispute Settlement Understanding (DSU) through dispute Panels and an Appellate Body. Countries seek the DSB's mediation when they believe agreements have been violated. The resulting processes generate an enormous volume of documents, including lengthy reports that are usually "carefully crafted" (Jackson 2000: 196) in English, and conscientiously translated into French and Spanish.

\section{Questions of method}

\subsection{The target-text oriented approach in the reconstruction of norms}

This contribution focuses on reconstructing translators' textual behavior by describing translational norms. There is no evaluative intention as any feature required to establish equivalence between linguistic versions is not considered "a postulated requirement, but an empirical fact" (Toury 1981: 13). The texts included in the corpus are part of the international legal system and are considered utterances of the target system (cf. Toury 1981: 11), that is, international legal texts uttered in Spanish. They are not considered derivative material (cf. Baker 2000) and, although relations to other texts in the system are assumed, these will not be the focus of this discussion.

The purpose is to establish how the existence of prescriptive norms in the system, in the form of utterances dictated by the institution and its different agents (revisers or senior translators through institutional glossaries), may have a standardizing effect on other utterances that are open to variability (specifically collocations).

\subsection{Researching collocations}

Sinclair's argument that the phrase is the "primary carrier of meaning" (2008: 409) has placed the study of phrase at the center of linguistic studies. Frequently occurring contiguous and non-contiguous combinations of two or more words that express a certain meaning, under different names ("lexical phrases", "extended lexical units", "extended collocations", "n-grams" or "lexical bundles"), are attracting growing attention from language and translation scholars. Methods have been developed to identify most common phrases to test hypotheses of register and genre variation, to characterize genres, to improve second language acquisition, or to develop computer-assisted translation tools (cf. Stubbs 2002, Biber 2006, Conklin/Schmitt 2007, 
Ellis et al. 2008, Römer 2010, Goźdź-Roszkowski 2011, Grabowski 2013, Buendía Castro/Faber 2014).

To cater to a different aim, the method will require some adjustments. Although the statistical approach is by far the most common in English studies, research on Spanish collocations tends to stress the semantic approach (Aguilar Amat 1993, Corpas Pastor 1996, Larreta Zulategui 2002, Zuluaga 2002, Sánchez Rufat 2010). In this paper, the aim is to discover to what extent Spanish legal translators at the WTO reproduce collocations not included in organizational glossaries (which would therefore be prescriptive). Although frequencies are a determining factor when trying to find an answer, a semantic target-oriented approach will allow us to locate the room for innovation and to discuss where variances are present.

Collocations will be extracted from the Spanish translation of panel reports derived from the (lack of) compliance with the Agreement on Subsidies and Countervailing Measures (C1, $12,014,055$ words), an area taken to reduce topic variability. These reports were originally drafted in English by independent experts and lawyers from the WTO Secretariat. The texts were then translated and revised in Spanish by professional staff working at the Secretariat. Collocations in this Spanish corpus will be extracted and then those included in institutional glossaries $^{3}$ will be discarded. The remaining bundles will be compared with those found in a corpus comprising the foundational agreements of the WTO (C2, 903,502 words), which are taken as the source of textual normality, beyond prescriptive equivalences dictated by glossaries.

Keywords from C1 were automatically extracted with AntConc (Anthony 2014) applying log-likelihood calculations in both subcorpora and using the CREA corpus (RAE 2005) as a reference corpus. ${ }^{4}$ For each keyword, extended collocations ( 3 to 5 word combinations) were extracted. Not being necessarily idiomatic, extended collocations allow for increased variability and were therefore best suited for our purposes. The five most frequent collocations for each keyword were then selected and classified. This classification aimed at distinguishing cases where translators may actually have different options from which to choose. The following categories follow Alonso's proposal (1994, 2001):

a) Terminological. Collocates whose combination produces a new meaning which cannot be derived from any of the elements (grupo especial, Spanish for 'panel', literally 'special group'; or estados unidos, 'united states').

b) Unique. Collocates that do not occur except in combination with the core element (palabra esdrújula, proparoxytone).

c) Semantic. Collocates sharing a semantic field with the core element (such as párrafo X del artículo $Y$, literally 'paragraph $\mathrm{X}$ in section $\mathrm{Y}^{\prime}$ ).

d) Auxiliary. Collocates whose meaning is altered in the combination (tomar una decisión, 'take a decision') although implying no changes in meaning for the lexical core and which can collocate with other lexical elements.

e) Elective. Collocates with an arbitrary relationship with the lexical core (such as el mencionado artículo or dicho artículo, 'aforementioned article'), where the core element does

3 Glossaries include the English term and equivalences in Spanish and French. They are generally presented as word lists although some have been introduced in a MultiTerm file. The lists include a total of 35,000 entries, including terms and common expressions in the institutional jargon.

4 In order of frequency: artículo, párrafo, unidos, acuerdo, grupo, especial, comunidades, medidas, Canadá, subvenciones, Europeas, informe, derechos, más, partes, China, productos, órgano, CE, Brasil, respecto, mercado, medida, precios, primera, subvención, prueba, parte, producción, sentido. 
not undergo any change in meaning and alternatives exist whose collocation produces a synonym expression.

This classification was meant to distinguish between collocations where translators had a real choice ( $\mathrm{d}$ and e) from those where choices were determined by the linguistic system (b), highly dependent on the topic and content, or even determined by glossaries provided by the organization ( $\mathrm{a}$ and $\mathrm{c}$ ).

Among the most frequent there are no collocations whose relation to the core is unique. The highly specialized nature of these texts is confirmed by a strong presence of terminological relations between the elements forming the collocation (43.9\%). For the most part of these cases, translators cannot find alternatives in the legal register. However, a fifth $(20.3 \%)$ of these terminological units were considered as such only because they were included in institutional glossaries. For instance establecimiento del grupo especial is included as an equivalent for 'establishment of the panel', when formación or creación are also possible and frequent collocates for panels in the Spanish legal register (referring to 'establishment' and not to its 'constitution' at a later stage). In other cases, although alternatives exist, the preference is shared in other legal settings, as in comunicación escrita as the Spanish version of 'written submission' instead of the linguistically possible comunicación por escrito.

The number of collocates that were classified as elective are second to terminological combinations, representing $34.7 \%$ of the total collocations under study. In these cases, at least one alternative is available but this is less used or most frequently disregarded. As an example the table shows units used in connection with articulo to express the meaning 'under the article', but preference is clearly given to de confomidad con.

Tab. 1: Collocates with the term artículo

\begin{tabular}{|l|c|c|}
\hline Collocates & Occurrences in C1 & Relative $\mathbf{\%}^{\mathbf{5}}$ \\
\hline de conformidad con el artículo & 2,876 & $44.5 \%$ \\
\hline en virtud del - & 1,824 & $28.2 \%$ \\
\hline con arreglo al - & 1,471 & $22.8 \%$ \\
\hline según el - & 208 & $3.2 \%$ \\
\hline de acuerdo con - & 83 & $1.3 \%$ \\
\hline
\end{tabular}

The preference in the CREA corpus (subcorpora 'justice and legislation' and 'law') is given to de acuerdo con el artículo, the least preferred alternative in C1. De conformidad con el artículo is third to según el artículo, and con arreglo al artículo is last after en virtud del artículo. Although the collocation of de acuerdo con with acuerdo ('agreement') simply does not work in Spanish, no parallelism can be found in the rest of the cases either. It is also noteworthy the preference in $\mathrm{C} 1$ for complex prepositions (all but según).

Less frequent were collocations showing a semantic relation between their constituent elements $(13.3 \%)$. In these cases the semantic fields concerned are trade, adjudication, and textual production, thereby attesting to the importance of the textual culture in international organizations. This is the case with párrafo $X$ del artículo $Y$ or frase del párrafo, among the five most frequent collocations of párrafo. The latter (literally, 'sentence in section') could also

5 In C2 artículo is used 212,129 times. This percentage takes into account only the occurrences of artículo with one of the collocates listed $(6,462)$. 
be considered as an elective combination, since alternatives include oración del párrafo, as strict synonym, but also lo expresado en el párrafo or la formulación del párrafo in the sense of 'wording'.

Tab. 2: Collocates with the term párrafo

\begin{tabular}{|c|c|c|}
\hline Alternatives & Occurrences in C1 & Relative $\%^{6}$ \\
\hline frase del párrafo & 3,947 & $78.1 \%$ \\
\hline oración del- & 1,054 & $20.8 \%$ \\
\hline lo dicho en el- & 13 & $0.3 \%$ \\
\hline lo expuesto en el - & 10 & $0.2 \%$ \\
\hline lo indicado en el- & 9 & $0.2 \%$ \\
\hline lo enunciado en el- & 9 & $0.2 \%$ \\
\hline lo señalado en el- & 6 & $0.1 \%$ \\
\hline la formulación del- & 4 & $0.1 \%$ \\
\hline lo expresado en el - & 1 & $0.0 \%$ \\
\hline lo afirmado en el- & 1 & $0.0 \%$ \\
\hline lo aseverado en el - & 1 & $0.0 \%$ \\
\hline lo consignado en el - & 1 & $0.0 \%$ \\
\hline lo sugerido en el- & 1 & $0.0 \%$ \\
\hline
\end{tabular}

Relatively few auxiliary collocations were found (8.2\%). In this case alternative options were always available, and they were sometimes even registered in notes to the relevant entries in institutional glossaries. One of the examples is objeto de apelación ('appealed'). The entry is not registered in institutional glossaries, but objeto de is indeed included under other headings. For instance, under the entry 'matter in dispute', asunto en litigio is given together with asunto objeto de litigio, where objeto is an auxiliary collocate. The lesser number of auxiliaries actually improves readability, as non-lexical alternatives reduce discourse density.

At this point, only bundles where alternative collocates had been identified were selected for the next phase of the analysis. The purpose was to determine whether agreements (C2) were taken as normative sources even when flexibility was possible, and, if so, how strictly or loosely the norm set by those texts was reproduced. The aim is to determine whether translators (or revisers) use their discretion to introduce variability or if they rather adhere to trends as if they were norms.

\section{From elective to normative?}

Collocations with a terminological relation to the lexical core were not taken into account for this part of the analysis, as choices are clearly restricted. Among clusters with a semantic relation between their constituent elements, few bundles were selected, as most were found in institutional glossaries or admitted no variation while preserving meaning. Those selected referred mostly to textual elements. Both párrafo ('paragraph') and artículo ('article' or 'sec-

6 In C2 párrafo is used 219,593 times. Percentages show the relative presence of the different collocates listed (out of a total of 5,057 occurrences). Only those carrying the meaning of 'wording' were taken into account. 
tion') appear in the keyword lists for $\mathrm{C} 2$ and $\mathrm{C} 1$, and were also found in the most frequent combinations for other keywords. The use of artículo was found to have no alternative (el artículo 1). Párrafo, however, was used as a synonym for apartado in $\mathrm{C} 1$, whereas the latter was exclusively used in the sense of 'subparagraph' in C2. Thus C1 departs from the norm in occurrences such as el párrafo $b$ or el párrafo $1 b$, where el apartado b or el apartado $1 b$ would be consistently used in $\mathrm{C} 2$.

Other clusters were more open to variations, such as those including disposiciones, which collocates with artículo and acuerdo ('agreement'). When taking the legal register as a whole, alternatives in Spanish include estipulaciones (0 occurrences in combination with acuerdo in both $\mathrm{C} 2$ and $\mathrm{C} 1$ ), preceptos (2 occurrences in $\mathrm{C} 2$ in this combination and 0 in C1), el contenido (not used in this combination, although co-occurring in both subcorpora), lo preceptuado (0 occurrences in this combination in $\mathrm{C} 2$ and 1 in $\mathrm{C} 1$ ), lo dispuesto (21 occurrences in $\mathrm{C} 2$ and 131 in $\mathrm{C} 1$ for this combination), and lo previsto ( 2 in $\mathrm{C} 2$ and 22 in $\mathrm{C} 1$ ). The tendency is clear, and the preferences established in $\mathrm{C} 2$ are reproduced in $\mathrm{C} 1$. Both corpora show an overwhelming preference for disposiciones (547 occurrences in this combination in C2 and 2,024 occurrences in $\mathrm{C} 1$ ).

When considering disposiciones in combination with articulo (disposiciones del artículo) both corpora share the most frequent alternative and options found in $\mathrm{C} 1$ are all present in $\mathrm{C} 2$. Variety is slightly reduced in $\mathrm{C} 1$, as one of the alternatives present in $\mathrm{C} 2$ cannot be found in $\mathrm{C} 1$.

Tab. 3: Collocates with the term disposiciones and their different frequencies (C1 and C2)

\begin{tabular}{|l|c|c|c|c|}
\hline Alternatives & Frequency C1 & \% & Frequency C2 & \% \\
\hline disposiciones del artículo & 483 & $63.0 \%$ & 185 & $59.5 \%$ \\
\hline lo dispuesto en el - & 238 & $31.0 \%$ & 76 & $24.4 \%$ \\
\hline lo establecido en el - & 32 & $4.2 \%$ & 23 & $7.4 \%$ \\
\hline lo previsto en el - & 12 & $1.6 \%$ & 24 & $7.7 \%$ \\
\hline el contenido del - & 2 & $0.3 \%$ & 1 & $0.3 \%$ \\
\hline lo preceptuado en el - & 0 & $0.0 \%$ & 2 & $0.6 \%$ \\
\hline estipulaciones del - & 0 & $0.0 \%$ & 0 & $0.0 \%$ \\
\hline preceptos del - & 0 & $0.0 \%$ & 0 & $0.0 \%$ \\
\hline
\end{tabular}

The trend is reversed in one case, la frase del párrafo, where $\mathrm{C} 1$ incorporates new alternatives that cannot be found in the agreements. 
Tab. 4: Frequencies for "frase del párrafo" and elective alternatives in C1 and C2

\begin{tabular}{|c|c|c|}
\hline Alternatives & $\mathrm{C1}$ & $\mathrm{C} 2$ \\
\hline frase del párrafo & 3,947 & 191 \\
\hline oración del- & 1,054 & 19 \\
\hline lo dicho en el- & 13 & 0 \\
\hline lo expuesto en el - & 10 & 0 \\
\hline lo indicado en el- & 9 & 0 \\
\hline lo enunciado en el - & 9 & 0 \\
\hline lo señalado en el- & 6 & 0 \\
\hline la formulación del- & 4 & 1 \\
\hline lo expresado en el - & 1 & 1 \\
\hline lo afirmado en el- & 1 & 0 \\
\hline lo aseverado en el - & 1 & 0 \\
\hline lo consignado en el - & 1 & 0 \\
\hline lo sugerido en el - & 1 & 0 \\
\hline
\end{tabular}

Another semantic combination would be texto ('text') in the frame el texto del artículo ('the text of the article'). Alternatives include términos ('terms') or phrases such as lo expresado or lo formulado ('what was expressed'), which occur in both $\mathrm{C} 2$ and $\mathrm{C} 1$, but also lo mencionado, lo referido, lo indicado or lo señalado, which do not appear in either corpora in combination with artículo (albeit some co-occur). Nevertheless, when compared with a reference corpus (RAE 2005), lo señalado is the most frequent option in the register 'Law' and 'Justice, Legislation'.

This same degree of homogeneity was found in auxiliary combinations, such as medida adoptada ('action agreed on' or 'approved measure'). Alternatives include medida tomada, aprobada, convenida, dispuesta, establecida, concertada, convenida. None of these alternatives occur in $\mathrm{C} 2$, and of the eight suggested three can also be found in $\mathrm{C} 1$, although the preference for adoptada is clear (316 occurrences vs. 53 for tomada, 29 for establecida and 1 for aprobada). When comparing these choices with results from the reference corpus (within the aforementioned register), adoptada is also preferred (69 occurrences), although the distance to the second option, tomada, is not significant (the latter is used 29 times), and dispuesta, aprobada and acordada are also present (7, 6 and 5 occurrences respectively). A look at documents from other international organizations, specifically the UN, shows how aprobada is the most frequent option among the given alternatives, thereby confirming the bearing of the organizational language (not only field-specific register) on translations.

Also auxiliary is the relation between different core elements and presente in el presente caso (literally, 'this present case') or el presente informe/acuerdo ('this present report/agreement'). The alternative considered in these cases was este ('this'), and the trend is consistent, as both $\mathrm{C} 2$ and $\mathrm{C} 1$ prefer el presente in combination with the name of the genre (report or agreement) but este in other clusters (asunto, procedimiento, análisis, grupo, escrito).

When considering elective combinations, which allow for the most flexibility, the preferences shown by $\mathrm{C} 1$ are parallel to those found in $\mathrm{C} 2$. This is the case for de conformidad con el párrafo \# ('under paragraph \#'). 
Tab. 5: Collocates with the term párrafo and their different frequencies (C1 and C2)

\begin{tabular}{|l|c|c|c|c|}
\hline Alternatives & Frequency C1 & $\mathbf{\%}$ & Frequency C2 & \% \\
\hline de conformidad con el párrafo & 2,018 & $37.0 \%$ & 365 & $51.2 \%$ \\
\hline en virtud del - & 1,524 & $27.9 \%$ & 168 & $23.6 \%$ \\
\hline con arreglo al - & 1,100 & $20.2 \%$ & 132 & $18.5 \%$ \\
\hline al amparo del - & 695 & $12.7 \%$ & 39 & $5.5 \%$ \\
\hline según el - & 89 & $1.6 \%$ & 7 & $1.0 \%$ \\
\hline de acuerdo con el - & 29 & $0.5 \%$ & 2 & $0.3 \%$ \\
\hline
\end{tabular}

Another interesting elective combination is con respecto al párrafo. Alternatives include con respecto del párrafo, respecto al párrafo, and respecto del párrafo. According to the Diccionario panhispánico de dudas (RAE 2005), the forms are synonym and currently the most common would be respecto $a$. However, $\mathrm{C} 1$ strongly reflects the preferences shown in $\mathrm{C} 2$.

Tab. 6: Different frequencies of collocates with respecto in the sense 'related to'

\begin{tabular}{|l|c|c|c|c|}
\hline Alternatives & Frequency C1 & \% & Frequency C2 & \% \\
\hline con respecto $a$ & 7,309 & $63.9 \%$ & 842 & $75.4 \%$ \\
\hline respecto $a$ & 484 & $4.2 \%$ & 30 & $2.7 \%$ \\
\hline con respecto de & 4 & $0.0 \%$ & 3 & $0.3 \%$ \\
\hline respecto de & 3,633 & $31.8 \%$ & 241 & $21.6 \%$ \\
\hline
\end{tabular}

Overall results seem to suggest that $\mathrm{C} 2$ is indeed taken as a normative source even when there would be room for alternatives, as exemplified by collocates with elective relations between the constituent elements. To confirm this trend, however, the list of keywords and bundles should be considerably expanded to further identify new clusters where alternatives are actually an option and analyze their behavior in the corpora.

\section{Creatures of habit?}

As seen in section 2.1, the position of translation in international organizations is somewhat particular. Texts translated into official languages are granted original and thereby central status, as the (translated) texts in those languages are independently taken as sources of legal rules and usually cannot become such unless all linguistic versions are available. Does this canonized and canonizing status result in translations occupying a more central and influential position in the system? Or do they show a conservative approach and preserve and reproduce conventional forms? Even-Zohar (1990: 50) theorized that, when translation is a primary product in the target system, translators do not feel constrained to follow existing models and are more prepared to "violate the home conventions". They are thus more prone to produce innovation through non-normal patterns. On the other hand, when translations are secondary, translators tend to use existing models, select linguistic options that are more common, and produce more 'non-adequate' and 'acceptable' translations. As a consequence there is a tendency towards a general standardization and loss of variation in style (Toury 1995: 268), as the translators accommodate to existing models. When this is the case, translation usually assumes a weak and peripheral position in the target system, and non-normal translations are assessed in negative terms. 
Even though, theoretically, the texts in this analysis are to be seen as canonical, results suggest a process towards standardization where institutional norms established in authoritative texts (C2) are reproduced in other genres (in this case, reports), even though variations are not totally stifled. The patterns show institutional specificities that do not necessarily reproduce those found in the general language or in the legal register used in other settings so a primary nature vis-à-vis other Spanish legal languages can be hypothesized. However, institutional norms become models beyond terminology and conceptual rendering, as opportunities for variations do not seem to be seized, and translators resort to authoritative texts in the search for norms pertaining to the collocation of elements also in elective combinations. Hermans (1998: 53) suggests that when adopting norms translators do so "with a view to securing some form of benefit, whether personal or collective, material or symbolic". It can be easily hypothesized that translators working for international organizations want their contracts to be extended by seeking revisers' approval, but other motivations can be expected, especially from revisers working on a permanent basis.

What lies behind the strong parallelisms between the corpora analyzed remains uncovered. The suggestion that agreements are taken as a source of normativity even when no norms have been dictated can partially account for the results, but offers no satisfactory explanation as to the identity between possible and actual variations in both genres. Further parameters need to be taken into account. Among those, the extent to which the one-to-one equivalence paradigm is followed would need to incorporate the source texts and the study of shifts. Studying group preferences, the intersubjective development of nuances and complexities, and the pursuance of certainty and other possible material or symbolic benefits would need to include the participants in drafting and translating and comparisons with translation behavior in other organizations. How socialization and continuous revisions affect a translator's willingness to innovate in cases where variation is possible, or how the necessity for homogeneity in terminological and discursive choices impacts their decisions regarding elective combinations are also open questions.

Norms are system-dependent, a sense made common for the members of a group, a doxa whose borders can be drawn with the descriptive and ethnographical approach towards which TS is steadily progressing. There is far more to this matter than meets the eye and it seems worthy approaching translators with no prescription as to what they should do, adopting instead Toury's descriptive project. With an ethnographical stance, the translators' definition of LIT can be reconstructed and its evolution in the workplace and its relation to norms prevailing in the organization can be examined. Translators have sufficiently proven to be complex creatures and how they introject, identify to, or integrate norms in the workplace still remains unclear. Hopefully not for too long.

\section{Acknowledgements}

I would like to thank my former colleagues and friends at the WTO for their staffing and all the information they shared: Susana Álvarez, Silvia Ávila, Beatriz Babío, Sebastián Briales, Juan Manuel Fernández, Luis Fdo. González, Pablo Pernetas Hernández, Gerardo Jiménez, Carlos Llull, Julieta López, Antonio Pérez, Juan Renard, Aníbal Rubio. 


\section{References}

Aceves, William J. (1996): "Ambiguities in plurilingual treaties: A case study of article 22 of the 1982 law of the sea convention." Ocean Development \& International Law 27.3: 187-233.

Aguilar Amat, Anna (1993): Las colocaciones de nombre y adjetivo. Un paso hacia una teoría léxico-semántica de la traducción. PhD thesis, Universitat Autónoma de Barcelona.

Ajulo, Sunday Babalola (1985): "Law, Language and International Organisation in Africa: The Case of Ecowas." Journal of African Law 29.1: 1-24.

Alonso Ramos, Margarita (1994): "Hacia una definición del concepto de colocación: de J.R. Firth a I.A. Mel'čuk." Revista de Lexicografía I: 9-28.

Alonso Ramos, Margarita (2001): “Construction d'une base de données des collocations bilingue françaisespagnol." Langages 143: 5-27.

Ammon, Ulrich (2006): "Language conflicts in the European Union. On finding a politically acceptable and practicable solution for EU institutions that satisfies diverging interests." International Journal of Applied Linguistics 16.3: 319-338.

Anthony, Laurence (2014): "AntConc." (v. 3.4.3) [Software]. Tokyo: Waseda University.

Baigorri Jalón, Jesús (1999): “Conference Interpreting: From Modern Times to Space Technology." Interpreting 4.1: $29-40$.

Baker, Mona (2000): "Towards a Methodology for Investigating the Style of a Literary Translator." Target 12: 241-266.

Berman, Antoine (1988): “Tradition, Translation, Traduction." Le Cahier 6: 21-38.

Biber, Douglas (2006): University Language: A Corpus-based Study. Amsterdam/ New York: Benjamins.

Biel, Łucja (2014): “The textual fit of translated EU law: a corpus-based study of deontic modality." The Translator: 1-24.

Bourdieu, Pierre (1977): “L'économie des échanges linguistiques." Langue Française 34: 17-34.

Bourdieu, Pierre (2002): "Les conditions sociales de la circulation internationale des idées." Actes de la recherche en sciences sociales 145: 3-8.

Buendía Castro, Miriam/Faber, Pamela (2014): “Collocation Dictionaries: A Comparative Analysis." MONTI 6: 203-235.

Cao, Deborah (2007): Translating Law. (Topics in Translation 33). Clevedon: Multilingual Matters.

Cao, Deborah (2013): "Legal Translation." The Encyclopedia of Applied Linguistics. Ed. Carol A. Chapelle. London: Wiley-Blackwell.

Condon, Bradly J. (2010): "Lost in Translation: Plurilingual Interpretation of WTO Law." Journal of International Dispute Settlement 1.1: 191-216.

Condon, Bradly J. (2012): "The concordance of multilingual legal texts at the WTO." Journal of Multilingual and Multicultural Development 33.6: 525-538.

Conklin, Kathy/Norbert Schmitt (2007): "Formulaic Sequences: Are They Processed More Quickly than Nonformulaic Language by Native and Nonnative Speakers?" Applied Linguistics 29.1: 72-89.

Cook, Graham (2012): "Defining the Standard of Proof in WTO Dispute Settlement Proceedings: Jurists' Prudence and Jurisprudence." Journal of International Trade and Arbitration Law 1.2: 49-72.

Corpas Pastor, Gloria (1996): Manual de fraseología española. Madrid: Gredos.

Covacs, Alexandre (1979): "Bilinguisme officiel et double version des lois." Meta. Journal des traducteurs 24.1: 103-108.

Ellis, Nick C./Simpson-Vlach, Rita/Maynard, Carson (2008): "Formulaic Language in Native and Second Language Speakers: Psycholinguistics, Corpus Linguistics, and TESOL." TESOL Quarterly 42.3: 375-396.

Even-Zohar, Itamar (1990): "Polysystem Studies.” Poetics Today 11: 27-44. 
Fernbach, Nicole M. (1995): “La simplification du texte juridique: étude comparative." Français juridique et science du droit. Eds. Gérard Snow/Jacques Vanderlinden. Bruylant/Bruxelles: Université de Moncton. 105-122.

Fiola, Marco A. (2004): “Le 'gain et le dommage' de l'interprétation en milieu social." TTR: traduction, terminologie, rédaction 17.2: 115.

Gallez, Emmanuelle/Maryns, Katrijn (2014): "Orality and authenticity in an interpreter-mediated defendant's examination: A case study from the Belgian Assize Court." Interpreting 16.1: 49-80.

Garzone, Giuliana (2000): "Legal Translation and Functionalist Approaches: A Contradiction in Terms?" La Traduction Juridique. Histoire, théorie(s) et pratique/Legal Translation. History, Theory/ies and Practice. Ed. GREJUT. Geneva: Université de Genève. 395-414.

Gémar, Jean-Claude (2013): "Translating vs Co-Drafting Law in Multilingual Countries: Beyond the Canadian Odyssey." Legal Translation in Context. Professional Issues and Prospects. Eds. Anabel Borja/Fernando Prieto. Bern et al.: Lang. 27-51.

Gouanvic, Jean-Marc (2002): "The Stakes of Translation in Literary Fields." Across Languages and Cultures 3.2: 159-168.

Goźdź-Roszkowski, Stanislaw (2011): Patterns of Linguistic Variation in American Legal English. A Corpus-Based Study. Frankfurt am Main et al.: Lang.

Grabowski, Łukasz (2013): “Register Variation Across English Pharmaceutical Texts: A Corpus-driven Study of Keywords, Lexical Bundles and Phrase Frames in Patient Information Leaflets and Summaries of Product Characteristics." Procedia - Social and Behavioral Sciences 95: 391-401.

Guo, Ting (2014): "Interpreting for the enemy: Chinese interpreters in the Second Sino-Japanese War (19311945)." Translation Studies 8.1: 1-15.

Hermans, Theo (1998): "Translation and Normativity." Current Issues In Language and Society 5.1-2: 51-72.

Hermans, Theo (2012): "Norms of Translation." The Encyclopedia of Applied Linguistics. Ed. Carol A. Chapelle. Oxford: Oxford University Press. 4262-4268.

ILC (International Law Commission) (1966): Yearbook of the International Law Commission. Geneva: United Nations.

Inghilleri, Moira (2003): "Habitus, Field and Discourse: Interpreting as a socially situated activity." Target 15.2: 243-268.

Inghilleri, Moira (2010): "You Don't Make War Without Knowing Why. The Decision to Interpret in Iraq." The Translator 16.2: 175-196.

Jackson, John Howard (2000): "The Role and Effectiveness of the WTO Dispute Settlement Mechanism." Brookings Trade Forum 2000.1: 179-219.

Kenny, Dorothy (1998): "Creatures of habit? What translators usually do with words." Meta. Journal des traducteurs 43.4: 515-523.

Koskinen, Kaisa (2000): "Institutional Illusions. Translating in the EU Commission.” The Translator 6.1: 49-65.

Koskinen, Kaisa (2008): Translating Institutions: an ethnographic study of EU translation. Manchester: St. Jerome.

Larreta Zulategui, Juan Pablo (2002): “En torno a la semántica de las colocaciones fraseológicas." Estudios de Lingüística 16: 5-41.

Levert, Lionel A. (1999): "Harmonization and dissonance: language and law in Canada and Europe." Bijuralism and Harmonization. Ed. Canada Department of Justice. 5-9.

Lie, Jon Harald Sande (2013): “Challenging Anthropology: Anthropological Reflections on the Ethnographic Turn in International Relations." Millennium: Journal of International Studies 41.2: 201-220.

Meylaerts, Reine (2010): "Habitus and self-image of native literary author-translators in diglossic societies." Translation and Interpreting Studies 5: 1. 
Mingxing, Yang (2012): "The principles and tactics on diplomatic translation: A Chinese perspective." Babel 58: 1-18.

Monzó Nebot, Esther (2005): "Being ACTIVE in Legal Translation and Interpreting: Researching and Acting on the Spanish Field. " Meta. Journal des traducteurs 50.4. 30.01.2015. https://www.erudit.org/revue/ meta/2005/v50/n4/019922ar.pdf.

Monzó Nebot, Esther (2011): "La explotación de corpus en los organismos internacionales." Lenguaje, Derecho y Traducción. Language, Law and Translation. Eds. Icíar Alonso Araguás/Jesús Baigorri Jalón/Helen Campbell. Granada: Comares. 117-155.

Narlikar, Amrita (2005): The World Trade Organization: A Very Short Introduction. Oxford: Oxford University Press.

OAU (Organisation of African Unity) (1963): Charter of the Organisation of African Unity. 30.01.2015. <http:// paxafrica.org/documents/resources/african-union-documents/charter-of-the-organisation-of-africanunity-oau-1963/view>.

Pasteur, Olivier (2013): “Technology at the Service of Specialized Translators at International Organizations." Legal Translation in Context. Professional Issues and Prospects. Eds. Anabel Borja/Fernando Prieto. Bern et al.: Lang. 283-297.

Prieto Ramos, Fernando (2013): "Legal Translation at the World Trade Organization." Legal Translation in Context. Professional Issues and Prospects. Eds. Anabel Borja Albi/Fernando Prieto Ramos. Bern et al.: Lang. 263-281.

Prieto Ramos, Fernando (2014): "International and supranational law in translation: from multilingual lawmaking to adjudication." The Translator 20.3: 313-331.

Pym, Anthony (2008): "On Toury's laws of how translators translate." Beyond Descriptive Translation Studies. Eds. Anthony Pym/Miriam Shlesinger/Daniel Simeoni. Amsterdam/Philadelphia: Benjamins. 311-328.

RAE (Real Academia Española) (2005): Diccionario panhispánico de dudas. 30.01.2015. <http://corpus.rae.es/ creanet.html>.

Römer, Ute (2010): “Establishing the phraseological profile of a text type: The construction of meaning in academic book reviews." English Text Construction 3.1: 95-119.

Sánchez Rufat, Anna (2010): "Apuntes sobre las combinaciones léxicas y el concepto de colocación." Anuario de Estudios Filológicos 33: 291-306.

Šarčevič, Susan (1997): New Approach to Legal Translation. The Hague/Boston: Kluwer Law International.

Šarčevič, Susan (2000): “Legal Translation and Translation Theory: a Receiver-oriented Approach." La Traduction Juridique. Histoire, théorie(s) et pratique/Legal Translation. History, Theory/ies and Practice. Ed. GREJUT. Geneva: Université de Genève. 329-347.

Sela-Sheffy, Rakefet (2005): "How to be a (recognized) translator. Rethinking habitus, norms, and the field of translation." Target 17: 1-26.

Shelton, Dinah (1997): "Reconcilable Differences? The Interpretation of Multilingual Treaties." Hastings International and Comparative Law Review 20: 611-638.

Simeoni, Daniel (1995): "Translating and Studying Translation: The view from the agent." Meta. Journal des traducteurs 40.3: 445-460.

Simeoni, Daniel (1998): "The Pivotal Status of the Translator's Habitus." Target 10: 1-39.

Sinclair, John M. (2008): "The phrase, the whole phrase, and nothing but the phrase." Phraseology: An interdisciplinary perspective. Eds. Sylviane Granger/Fanny Meunier. Amsterdam/Philadelphia: Benjamins. 407-410.

Stubbs, Michael (2002): "Two quantitative methods of studying phraseology in English." International Journal of Corpus Linguistics 7.2: 215-44. 
Toury, Gideon (1978): "The nature and role of norms in literary translation." Literature and Translation. New Perspectives in Literary Translation. Eds. James S. Holmes/José Lambert/Raymond van den Broeck. Leuven: Acco. 83-100.

Toury, Gideon (1981): “Translated Literature: System, Norm, Performance: Toward a TT-Oriented Approach to Literary Translation." Poetics Today 2.4: 9-27.

Toury, Gideon (1995): Descriptive Translation Studies and Beyond. Amsterdam/Philadelphia: John Benjamins.

UN (United Nations) (1969): Vienna Convention on the law of treaties. Concluded at Vienna. Treaty Series 1155 , 1-18232 (23 May 1969).

UN General Assembly (1946): Rules of procedure concerning languages. London: $1^{\text {st }}$ session, $21^{\text {st }}$ plenary meeting (1 February 1946).

UN General Assembly (1980): Use of Arabic in the subsidiary organs of the General Assembly, in the Security Council and in the Economic and Social Council. New York: $28^{\text {th }}$ session, $99^{\text {th }}$ plenary meeting. Resolution 35/219 (17 December 1980).

Valdés, Guadalupe/Chávez, Christina/Angelelli, Claudia/Enright, Kerry/González, Marisela/García, Dania/Wyman, Leisy (2000): “Bilingualism from another perspective. The case of young interpreters from immigrant communities." Research on Spanish in the United States: Linguistic Issues and Challenges. Ed. Ana Roca. Somerville: Cascadilla Press. 42-81.

Valero Garcés, Carmen/Gauthier, Laura (2010): “Bourdieu and Public Service Interpreting and Translation: Towards a Social Theory in PSIT. " MONTI 2: 97-117.

Venuti, Lawrence (1992): Rethinking Translation. Discourse, subjectivity, ideology. London/New York: Routledge.

Vidal Claramonte, África (2005): "Re-presenting the 'Real': Pierre Bourdieu and Legal Translation." The Translator 11.2: 259-275.

Vidal Claramonte, África/Martín Ruano, Rosario (2003): "Deconstructing the discourse on legal translation." Speaking in tongues: language across contexts and users. Ed. Luis Pérez González. Valencia: Universitat de València. 141-159.

Villeneuve, Suzanne (2001): “Closing Remarks." Paper presented at Critical Link 3. Third International Conference on Interpreting in Legal, Health and Social Service Settings, Montréal, 22-26 May.

Wolf, Michaela (1999): "Zum Sozialen Sinn in der Translation." Arcadia 34.2: 262-273.

Wolf, Michaela (2007): "The location of the translation field. Negotiating borderlines between Pierre Bourdieu and Homi Bhabha." Constructing a Sociology of Translation. Eds. Michaela Wolf/Alexandra Fukari. Amsterdam/Philadelphia: Benjamins. 109-119.

Zuluaga, Alberto (2002): “Los 'enlaces frecuentes' de María Moliner. Observaciones sobre las Ilamadas colocaciones." LEA: Lingüística Española Actual 24: 97-114.

Esther Monzó Nebot

Karl-Franzens-Universität Graz, Austria

Universitat Jaume I, Spain

FCHS-Departmet of Translation and Communication

Av. Sos Baynat s/n - E12071 Castelló, Spain

monzo@uji.es 